\title{
The Impact of Accounting Information Comparability on Audit Time Lag
}

\author{
Fenting Zheng ${ }^{1, a, *}$
}

\author{
${ }^{I}$ Accountancy, Nanjing University of Science and Technology, Nanjing, Jiangsu, China \\ ${ }^{a} z f t 0502 @ 163 . c o m$ \\ *Corresponding author
}

\begin{abstract}
The comparability of accounting information of companies in the same industry reflects the similarity and relevance of the company's operating environment and financial reporting. Comparability helps users of accounting information to identify similarities and differences in economic matters, and improves the usefulness of accounting information. Although both the FASB and the SEC have emphasized the importance of comparability of accounting information, few empirical studies have examined the impact of comparability of accounting information on audit lags. From an information efficiency perspective, comparability helps auditors reduce the cost of information acquisition, processing, and testing, thereby speeding up the release of audit reports. From the perspective of audit risk, the increase in the comparability of accounting information may lead to the tendency of executives to adopt more real earnings management for more hidden self-interest, thereby increasing audit risk and audit complexity. As a result, auditors need to spend more time reducing audit risks. So, is the impact of comparability of accounting information on audit lags positive or negative? In order to explore this issue, this paper conducts research by using 8,223 observations of listed companies in Shanghai and Shenzhen from 2013 to 2017 in the CSMAR database. After empirical research, the results show that under the same conditions, the higher the comparability of accounting information, the longer the audit report lag. This paper makes up for the lack of research on accounting comparability in the existing literature, enriches the relevant literature on audit delays, and has a certain impact on the audit activities of audit institutions and corporate management.
\end{abstract}

\section{Keywords: accounting information comparability, audit lag, information efficiency, audit risk}

\section{INTRODUCTION}

External audit requires human and time costs, so the audit report signing date is behind the balance sheet date; in order to better monitor the capital market, stock exchanges and other regulatory agencies require that listed companies Disclose the audited annual financial information within the prescribed period, that is, the annual financial report and the audit report. For example, in the UK, a listed company must publish its annual financial report within 6 months of the fiscal year deadline. However, Australian listed companies are required to disclose within 4 months of the end of the fiscal year. The same is true in China, which is within four months of the balance sheet date.

The security market highly relies on the effectiveness and timeliness of information. In the emerging capital market, the efficiency of capital market can be greatly improved by publishing financial information as soon as possible. To a large extent, this is closely related to the length of audit delay, which determines whether financial information can be timely and effectively communicated to external information users. The longer the audit delay is, the later the financial information is disclosed, and the information users who use the financial report to make relevant decisions will face higher risks. The more timely financial information is released, the less uncertainty and risk information users have in making relevant decisions, the more accurate their investment decisions based on financial information, and the more conducive to the development of capital market economy. Audit delay is related to the timeliness and effectiveness of financial information disclosure, which is one of the few indicators that can be used to quantify audit efficiency. The value of accounting information delivered to information users by audited financial reports will gradually decrease with the increase of audit delay. The value of outdated accounting information is greatly reduced. Therefore, the exploration and Research on the influencing factors of audit delay is of great significance to improve the timeliness and effectiveness of accounting information transmission.

However, for the empirical problem of whether the comparability of accounting information between the audited company and the company in its industry has an impact on the audit time of the client company, few scholars have explored and studied it, and there are not many relevant literature. From the perspective of information quality between companies and audit efficiency of auditors, this paper explores and discusses the above issues. On the one hand, from the perspective of information efficiency, the comparability of accounting information helps auditors reduce the cost of information acquisition, processing and testing, thus reducing the audit complexity of auditors, so that auditors can relatively invest less time and energy in audit work, so as to speed up the issuance of audit reports. On the other hand, from the perspective of audit risk, the 
improvement of the comparability of accounting information may lead the executives to adopt more real earnings management. In order to make the results of financial statements more beneficial to the development of the company, they can achieve the purpose of maintaining more hidden self-interest. However, the more real earnings management, the more audit risk and audit complexity, so auditors need to spend more time to reduce audit risk. To sum up, how the comparability of accounting information affects the audit delay is an issue that needs to be explored with empirical research.

\section{LITERATURE REVIEW}

In the Accounting Standards for Business Enterprises-Basic Standards issued by China, the comparability of accounting information is defined as follows: "The accounting information provided by enterprises should be comparable. The same or similar transactions or events occurring in different periods of the same enterprise shall adopt the same The accounting policies of the company shall not be changed at will. The same or similar transactions or events between different enterprises shall adopt prescribed accounting policies to ensure that the caliber of accounting information is consistent and mutually comparable. "This not only reflects the verticality of the accounting information in the time dimension. Comparability also reflects the level of comparability of accounting information in the spatial dimension. However, China's current definition of comparability of accounting information is relatively empty, and there is no clear and detailed explanation.

In the early days, there were few related research literatures on the comparability of accounting information. In recent years, the research on the comparability of accounting information has gradually increased. Gu Min[1]pointed out that users of accounting information always need to have comparable information, and hope that the amount of information is large and detailed. However, no matter how hard you try to do well, companies may not be able to do their best objectively. Therefore, it is necessary to face up to the constraints and development trends of comparability of accounting information for comprehensive consideration and evaluation.

There are many factors affecting the comparability of accounting information, and more and more interested scholars have conducted research and analysis on this. Liu Yanghui[2] found that the CPAs who signed the audit had industry expertise, and their audit matching client companies' accounting information was more comparable than other companies. Research by Franco et al. [3] found that accounting information is more comparable between companies in the same industry or similar capital sizes. Xue Yuhua and Zhang Pengcheng [4] found that agency costs had an inverse effect on the comparability of accounting information, and further found that the agency problem of state-owned enterprises had a more negative impact on the comparability of accounting information than non-state-owned enterprises. Compared with local state-owned enterprises, the problem of agency problems in central enterprises is more negative.

Some other scholars have carried out related research on the impact of comparability of accounting information on audit quality, audit cost, earnings management, and accounting firm replacement. Franco et al. [3] and Kim et al. [5] believe that more comparable accounting information can effectively reduce the cost of information acquisition and processing, thereby reducing information asymmetry and improving the understandability and practicality of financial information. Cheng Meng and Liu Ruizhi[6] found that the comparability of accounting information has a negative impact on the level of earnings manipulation of listed companies, that is, the comparable performance of accounting information improves the audit quality of auditors. Chen Kun and Jiang Xuanyu[7] research found that there is a significant negative correlation between the comparability of accounting information and audit costs, and a reduction in audit workload can significantly reduce audit costs. Sun Lixia[8] believes that improving the comparability of accounting information can reduce the supervision and audit costs of supervisors and auditors. Through empirical analysis, it is further found that the comparability of accounting information has a negative impact on the earnings management of accrued items of listed companies, and has a significant positive impact on the true earnings management of listed companies. It further illustrates that improving accounting information can reduce auditors' review costs. Yan Min and Qu Chenchen [9] hold the same views as Shi Jun[10] and Lan Hao[11]. They all find that when the comparability of accounting information is high, the client company's accrual earnings management behavior will be less. In turn, they tend to adopt more real earnings management behaviors. Xie Shengwen et al.[12] thought that the comparability level of the audited company's accounting information affected the professional judgment of the auditors, and then affected the auditors' corresponding decisions. Therefore, the lower the comparability of accounting information, the more likely the accounting firm will change. Chen Xiangyu et al. [13] found that the higher the comparability of accounting information, the higher the accuracy of corporate management performance prediction; a good internal and external information environment can enhance the positive correlation between the comparability of accounting information and the accuracy of performance prediction.

Audit lag, also known as audit delay, is generally defined as the number of days between the balance sheet date and the date of signing the audit report; however, some scholars also consider it as the disclosure lag of the audit report, which is the balance sheet The number of days from the date the audit report is issued. Liu Yali et al. [14] used the two indicators of audit delay and disclosure delay as the annual report disclosure delay, and studied the impact of various factors on the timeliness of annual report disclosure. The study found that the impact of audit delay on the annual report disclosure delay was greater than the disclosure delay. That is, audit delays account for most of the delay in annual reporting. There are numerous researches on the audit lag in academia, especially the research literature on the factors affecting audit delay and disclosure delay.

Gong et al. [15] believed that the shorter the audit time, the higher the audit efficiency and the more effective the audit. If the more time it takes to perform the audit, the slower the progress, the lower the efficiency of the audit. Habib, Bhuiyan[16] found that auditors with industry expertise can execute audit plans faster and better than auditors without 
industry expertise. Chen Gaocai[17] found that the audit lag of non-standard opinions was significantly prolonged. Chan et al. [18] concluded that companies with long lags in audit reports are more likely to receive non-standard opinions in subsequent periods. Not only that, companies with very long audit lags will usually have more repetitions in the coming year.

Yang Mingzeng et al. [19] found that from 2003, the audit lag of China's listed companies has an increasing trend. In 2007, after China began to implement a modern risk-oriented audit model, this growth trend is even more For obvious reasons, the disclosure period of the audit report was greatly delayed. Zhang Huijun[20] research found that whether the company changed its accounting firm, the company 's operating performance, the company 's company size, asset-liability ratio, whether it was a standard audit opinion, the timing of the company 's change of its accounting firm, and the size of the accounting firm all significantly affected the audit report Delay; the factor of whether the company's ST will positively affect the delay of the audit report, but the effect is not significant; independent directors will significantly negatively affect the delay of the audit report.

Audit time lag directly affects the timeliness of accounting information. The shorter the audit time lag, the more valuable the information transmitted. Therefore, the exploration of the time lag of audit reports focuses on the study of its influencing factors. In general, the existing literature mainly considers the characteristics of companies and auditors.

From the existing empirical evidence of developed and emerging markets, there are few studies on how auditors use the comparability of accounting information when they perform audit. Joseph, Zhang [21] believe that providing comparable customer information can help improve audit efficiency and accuracy, that is, the comparability is negatively related to audit delay. However, Yuan Zhenchao and Wei Xiaoquan[22] found that the comparability of accounting information can not alleviate the audit delay, but lead to a longer audit delay without considering the auditor's industry expertise.

\section{HYPOTHESIS PUT FORWARD}

Due to information asymmetry and principal-agent problems, the reliability of annual reports provided by the company's management is easily questioned by the users of financial reports. Therefore, the audit report issued by an independent third party, i.e. an accounting firm, is of great importance. The auditors' audited accounting information is more reliable and valuable. Highly comparable accounting information can effectively reduce the cost of information acquisition and processing, alleviate information asymmetry, and improve the comprehensibility and usefulness of financial information[3] [5]. The higher the comparability of the two companies, the smaller the difference in economic matters between the two companies, and the higher the degree of similarity, which means the higher the comparability of accounting information between the two companies. Highly effective use of comparable accounting information can enable auditors to share relevant knowledge in the audit work, thus reducing the cost of seeking relevant information of the audited company, improving the audit efficiency and shortening the audit time. Therefore, the audit report can be more timely disclosed and effectively transmitted to external information users. To sum up, according to the action path of "improving the information environment by comparing accounting information - improving audit efficiency shortening audit delay", this paper puts forward the following hypothesis $1 \mathrm{~A}$ :

Hypothesis 1A: under the same other conditions, the higher the comparability of accounting information, the shorter the audit delay of audit report.

However, the higher the comparability of accounting information, in turn, will lead to the emergence and increase of other opportunistic behaviors of executives, which will increase the risk level of auditors in the audit of the audited company. Therefore, in order to reduce the audit risk, auditors need to obtain more sufficient information and powerful by increasing audit procedures, expanding the scope of substantive tests and other ways Evidence, naturally, their time and energy will be greatly increased, and the audit end date will be delayed later, so the audit delay will increase accordingly. Zang [23] ound that the executives of the company compared the relative cost of the corresponding accrual earnings management with the relative cost of the real earnings management, and then chose the lower one of the two kinds of earnings management, making the results of the annual report show the expected effect, so as to achieve the purpose of maintaining their own interests. According to $\mathrm{Xu}$ Chaoyang and Liu Ruizhi[24], the higher the comparability of accounting information, the more difficult it will be for executives to carry out accrual project earnings management. Then, due to the existence of principal-agent problem, executives will adopt a more concealed earnings management method to replace it. They found that the relationship between real earnings management and accrued earnings management is always a substitution. When the accounting information of the company and other companies in the industry is more comparable, executives tend to adopt real earnings management, otherwise they are more likely to adopt accrual earnings management[23] [25].

The higher the comparability of accounting information is, the higher the transparency of information will be, and the motivation of company management to change from accrual earnings management to real earnings management will be greatly increased. Because in general, the real earnings management is more hidden and difficult to be found by auditors. Generally speaking, it is difficult to distinguish the real earnings management by the conventional audit procedures and means, because it may be achieved by the real transaction arrangement, which will lead to the auditors facing greater audit risk. For auditors, on the one hand, if executives whitewash the company's performance through real earnings management, which leads to a false high share price, then the investors who lose may file a lawsuit against the relevant auditors in the later stage, which improves the litigation risk faced by auditors. On the other hand, real earnings management may cause the quality of the company's overall accounting information to decline, and make it more difficult to detect the accrual earnings management[26]. Although real earnings management may not directly violate accounting standards, it is more difficult for auditors to find it than accrual earnings management without violating accounting standards[10] [11]. This will increase the risk and complexity of audit, make audit more 
stata15.1 statistical software. Finally, 8223 observations were obtained after data processing, among which $1 \%$ and $99 \%$ of the continuous variables were tailed to eliminate the influence of extreme values on the research results.

\subsection{Definition of Variables}

\subsubsection{Audit Delay}

Audit delay, also known as audit delay, is generally interpreted as the number of days from the balance sheet date to the signing date of the audit report; however, in some scholars' relevant research, the audit delay is defined as the number of days between the annual report disclosure delay, that is, the balance sheet date and the audit report date.

In this paper, the audit delay of the explained variable is measured by the natural number of calendar days between the audit end date and the accounting year end date. And use the alternative variable annual report disclosure delay (delay1), that is, the natural number of days between the balance sheet date and the audit report date to measure, and further test the robustness to make the results more reliable.

\subsubsection{Comparability of Accounting Information}

Compared with other variables, the measurement of accounting information comparability is more complex. In this paper, we refer to the measurement method of accounting system comparability built by Franco et al.[3]. At the same time, we use the relevant research of Joseph, Zhang [21], yuan Zhenchao and Wei Xiaoquan[22] for reference to calculate the measurement of accounting information comparability of company I. The specific methods are as follows:

The above sample data are all from CSMAR Taian database, and the data analysis is conducted by Excel, spss 22.0 and

$$
\begin{gathered}
\text { AcctCompind } \left.\left._{i, j, t}=(-1 / 16) * \sum_{t-15}^{t} \mid \mathrm{E} \text { (earnings }\right)_{i, i, t}-\mathrm{E} \text { (earnings }\right)_{i, j, t} \mid \\
\text { AcctCompind }_{i, t}=\left(\sum_{i=1}^{n} \text { AcctCompind }_{i, j, t}\right) / n^{*} 100
\end{gathered}
$$

The greater the calculated value of the comparability of accounting information, the higher the comparability of the accounting information of the company with its industry.

\subsubsection{Control Variables}

In order to ensure that the research conclusions obtained are more accurate, this paper refers to many research models and conclusions from domestic and foreign literature. According to the research object of this article, namely audit lag, relevant factors that have an important impact on audit delays are selected as control variables The variables are defined as shown in Table 1. 
Table 1 Definition of variables

\begin{tabular}{ll}
\hline Variable & Variable definition \\
\hline Delay & Natural logarithm of calendar days between audit end date and accounting year end date \\
AcctCompind & Refer to the calculation of Franco [3] comparability measurement method. See 4.2.2 for details \\
Size & Natural logarithm of total assets at the beginning of the period. \\
Roa & Ratio of net profit after deducting non recurring profit and loss to total assets at the beginning of the \\
period & Ratio of total liabilities at the beginning of the period to total assets at the beginning of the period \\
Gev & Growth rate of main business income \\
Loss & If the net profit after deducting non recurring profit and loss in the current year is negative, the value \\
Segment & is $1 ;$ otherwise, it is 0. \\
Opin & The number of business departments of the company plus the natural logarithm of 1. \\
& If the company is issued with standard unqualified audit opinion in the current year, the value is $1 ;$ \\
Big4 & otherwise, it is 0. \\
Ind & If the company is audited by four major international auditors in the current year, the value is $1 ;$ \\
otherwise, it is 0.
\end{tabular}

\subsection{Model Construction}

Referring to the research models of Franco et al.[3] , Joseph h, Zhang.[21], Yuan Zhenchao, Wei Xiaoquan[22] and Zhang Huijun[20], the test models for hypothesis are as follows:

$$
\begin{aligned}
\text { Delay }_{i, t}=a_{0} & +a_{1} \text { AcctCompind }_{i, t}+a_{2} \text { Size }_{i, t}++a_{3} \text { Roa }_{i, t}+a_{4} \text { Lev }_{i, t}+a_{5} \text { Growth }_{i, t} \\
& +a_{6} \text { Loss }_{i, t}+a_{7} \text { Segment }_{i, t}+a_{8} \text { Opin }_{i, t}+a_{9} \text { Big }_{i, t}+a_{10} \text { Ind }_{i, t}+\text { Year } \\
& + \text { Industry } \varepsilon
\end{aligned}
$$

\section{EMPIRICAL ANALYSIS}

\subsection{Descriptive Statistics}

The above are descriptive statistics of the variables for all samples. According to Table 2, we know that there are 8223 data samples of companies studied in this paper. The average value of the natural logarithm of the audit lag, that is, the date between the date of issue of the audit report and the end of the fiscal year, is 4.549, indicating that the interval between the issue of the auditor's report and the end of the fiscal year is about 93 days after the end of the fiscal year According to China's regulations, the annual report disclosure must be before April 30 of the second year, that is, the audit lag cannot exceed 120 days. It can be seen that the audit delay of China's listed companies' annual reports is generally longer. The average value of comparability of accounting information is -0.016 , the maximum value is 0.000 , and the minimum value is -0.108 . The range is large, indicating that the distribution of the comparability of accounting information is scattered, indicating that the average deviation of each company from other companies in its industry is about market value. $1.6 \%$; the average size of the company is 22.163 , the maximum is 26.070 , and the minimum is 19.580 . It can be found that the sample companies have significantly different company sizes and there are large differences among different companies; the proportion of independent directors in the board of directors, whether the company is losing money, and assets The same applies to other control variables such as debt ratio and growth rate of main business income.

Table 2 Descriptive statistics for the entire sample

\begin{tabular}{cccccc}
\hline Variable & number of samples & mean & standard deviation & minimum & maximum \\
\hline Delay & 8223 & 4.549 & 0.498 & 4.000 & 5.000 \\
Acctcompind & 8223 & -0.016 & 0.02 & -0.108 & 0.000 \\
Ind & 8223 & 0.375 & 0.053 & 0.333 & 0.571 \\
Loss & 8223 & 0.097 & 0.297 & 0.000 & 1.000 \\
Lev & 8223 & 0.432 & 0.213 & 0.053 & 0.940 \\
Roa & 8223 & 0.035 & 0.052 & -0.180 & 0.180 \\
Growth & 8223 & 0.232 & 0.626 & -0.612 & 4.503 \\
Size & 8223 & 22.163 & 1.292 & 19.580 & 26.070 \\
Opin & 8223 & 0.964 & 0.187 & 0.000 & 1.000
\end{tabular}




\begin{tabular}{cccccc} 
Big4 & 8223 & 0.054 & 0.226 & 0.000 & 1.000 \\
Segment & 8223 & 2.633 & 0.999 & 0.000 & 6.672 \\
\hline
\end{tabular}

\subsection{Correlation Analysis}

Table 3 Correlation analysis results

\begin{tabular}{|c|c|c|c|c|c|c|c|c|c|c|c|}
\hline Variable & Acctcomp & Delay & Ind & Loss & Lev & Roa & Growth & Size & Opin & Big4 & Segment \\
\hline \multicolumn{12}{|c|}{ Acctcomp 1.000} \\
\hline Delay & $0.081 * * *$ & 1.000 & & & & & & & & & \\
\hline Ind & 0.002 & -0.011 & 1.000 & & & & & & & & \\
\hline Loss & $-0.056 * * *$ & $0.101 * * *$ & -0.005 & 1.000 & & & & & & & \\
\hline Lev & $-0.117 * * *$ & 0.015 & $-0.054 * * *$ & $0.181 * * *$ & 1.000 & & & & & & \\
\hline Roa & -0.007 & $-0.110 * * *$ & 0.008 & $-0.648 * * *$ & $-0.370 * * *$ & 1.000 & & & & & \\
\hline Growth & $0.028 * *$ & $0.022 * *$ & 0.012 & $-0.129 * * *$ & $0.020^{*}$ & $0.152 * * *$ & 1.000 & & & & \\
\hline Size & $-0.186 * * *$ & $-0.040 * * *$ & $-0.027 * *$ & $-0.095 * * *$ & $0.499 * * *$ & 0.000 & $0.037 * * *$ & 1.000 & & & \\
\hline Opin & 0.005 & $-0.100 * * *$ & $0.031 * * *$ & $-0.234 * * *$ & $-0.163 * * *$ & $0.247 * * *$ & 0.015 & $0.113^{* * *}$ & 1.000 & & \\
\hline Big4 & $-0.096 * * *$ & $-0.130 * * *$ & $0.023 * *$ & $-0.044 * *$ & $0.133 * * *$ & $0.026^{* *}$ & -0.014 & $0.355^{* * *}$ & $0.026^{* *}$ & 1.000 & \\
\hline Segment & $-0.065 * * *$ & $0.032 * * *$ & -0.014 & $-0.069 * * *$ & $0.344 * * *$ & -0.003 & $0.035^{* *}$ & $0.621 * * *$ & $0.081 * * *$ & $0.168 * * *$ & 1.000 \\
\hline
\end{tabular}

Table 3 shows the relevant test results of the model. As shown in the table, in terms of the dependent and independent variables, the comparability of the accounting information of the sample company and the interval between the end of the audit date and the end of the fiscal year are significantly correlated at a significance level of $1 \%$, and the coefficient is positive. That is to say, the comparability of accounting information will have a significant positive impact on the interval between the end of the audit and the end of the fiscal year, which initially confirmed the hypothesis 1B; as far as the independent variables are concerned, although the relationship between the variables is significant, the correlation coefficient The absolute value is not very large, so it is considered that the multicollinearity does not exist or is not obvious, and the relationship between them can be further analyzed by modeling.

\subsection{Multiple Collinearity Test}

In order to improve the rigor of the research, this paper analyzes the VIF and tolerance of the independent variables of each model. Variance expansion factor (VIF) refers to the ratio of the variance between the explanatory variables when there is multicollinearity and the variance when there is no multicollinearity. The larger the VIF, the more serious the colinearity. Empirical judgment methods show that when 0 $<\mathrm{VIF}<10$, there is no multicollinearity; when $10 \leqslant \mathrm{VIF}<100$, there is strong multicollinearity; when VIF $\geqslant 100$, there is severe multicollinearity, and the tolerance is the reciprocal of VIF, usually it is considered that there is no multicollinearity greater than 0.1 Collinearity. This article examines the linear correlation between the variables' VIF and tolerance for each model. As shown in Table 4, the VIF values of all independent variables are less than 10 , and the tolerance is greater than 0.1 . There is no problem of multicollinearity.
Table 4 Multicollinearity results

\begin{tabular}{ccc}
\hline Variable & VIF & 1/VIF \\
\hline Acctcompind & 1.09 & 0.91333 \\
Big4 & 1.17 & 0.854841 \\
Growth & 1.05 & 0.949726 \\
Ind & 1.02 & 0.983253 \\
Lev & 1.87 & 0.536102 \\
Loss & 1.8 & 0.555557 \\
Opin & 1.13 & 0.881743 \\
Roa & 2.04 & 0.489075 \\
Segment & 1.76 & 0.567011 \\
Size & 2.55 & 0.391589 \\
\hline Mean & 1.86 & \\
\hline
\end{tabular}

\subsection{Regression Analysis}

\subsubsection{Full-sample Regression Analysis}

From the previous analysis results of the correlation between the variables, we can preliminary understand the level of correlation between them. Next, this article continues to apply the method of multiple regression analysis to more specifically analyze the comparability of audit time lags and accounting information and various controls. The quantitative relationship between the variables, and explore whether the relationship is more in line with Hypothesis 1a or Hypothesis 1B.

As can be seen from Table 5, for the model in this paper, the $\mathrm{R}$-square value is 0.060 , indicating that the model fits well, 
of return on assets, the growth rate of the main business income, whether to issue a standard unreserved audit opinion, the number of company business units, and whether it has been significantly affected by the four major international audits at $1 \%$. The level of audit is significant, in which the audit lag is related to the rate of return on assets, whether to issue a standard unqualified audit opinion, whether it is negatively related to the four major international audits, and whether it is a loss, and the number of business units is positively correlated; There is a positive correlation between the lag and the growth rate of main business income, and it passed the test at a significance level of $5 \%$. which confirms hypothesis $1 \mathrm{~B}$. It can also be seen that in the data of the entire sample company, the audit lag and the rate

Table 5 Regression results for all samples

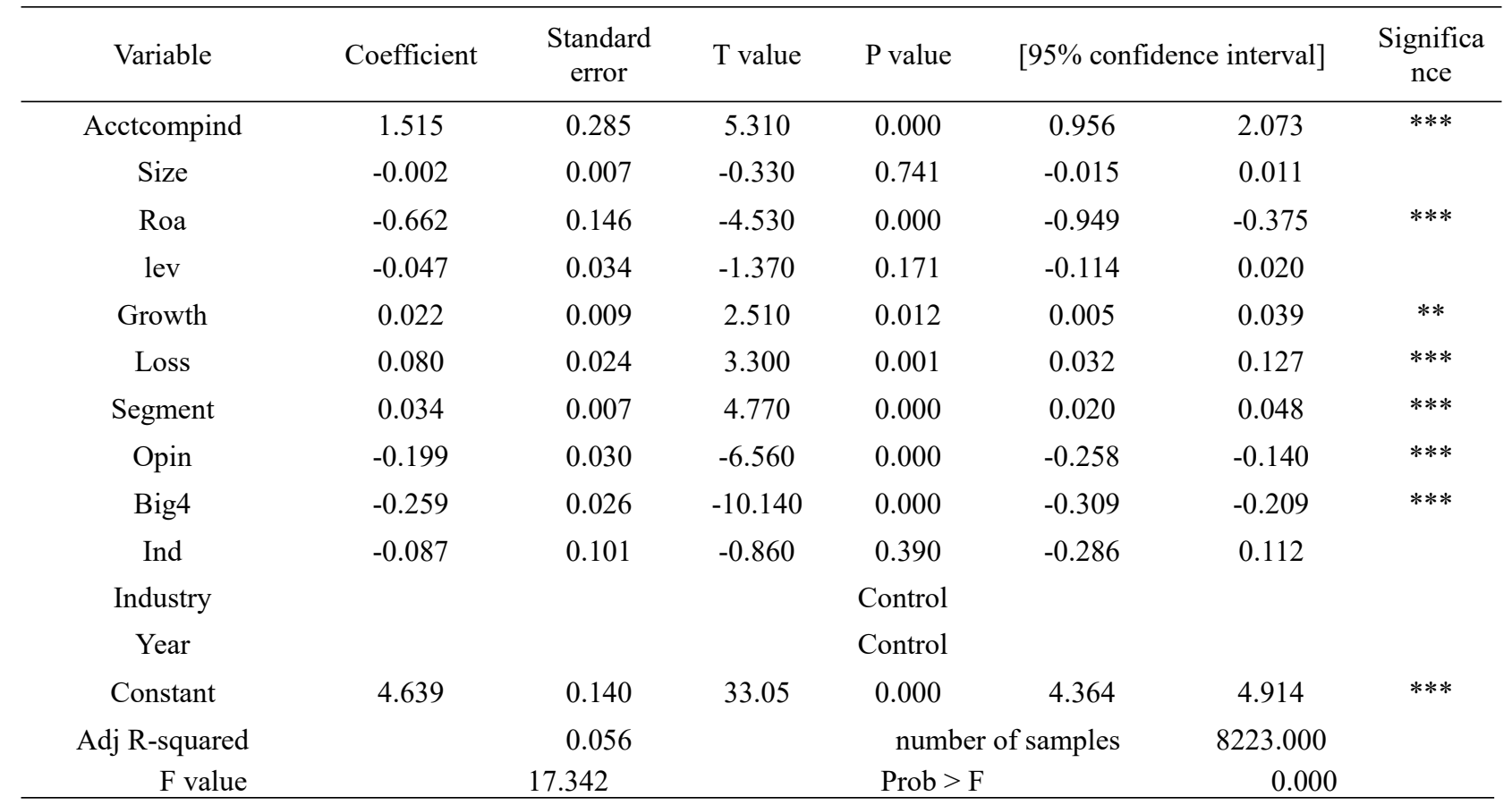

$* * * p<0.01, * * p<0.05, * p<0.1$ 


\subsubsection{Annual Regression Analysis}

Table 6 Annual regression analysis results

\begin{tabular}{|c|c|c|c|c|c|}
\hline Variable & 2013 & 2014 & 2015 & 2016 & 2017 \\
\hline Acctcompind & $\begin{array}{r}3.592 * * * \\
(7.340)\end{array}$ & $\begin{array}{r}2.403 * * * \\
(4.690)\end{array}$ & $\begin{array}{r}3.990 * * * \\
(6.600)\end{array}$ & $\begin{array}{c}1.334 * * \\
(2.390)\end{array}$ & $\begin{array}{r}1.832 * * * \\
(3.330)\end{array}$ \\
\hline Size & $\begin{array}{l}-0.331 \\
(-1.360)\end{array}$ & $\begin{array}{l}0.364 \\
\quad(1.460)\end{array}$ & $\begin{array}{l}-0.146 \\
(-0.640)\end{array}$ & $\begin{array}{l}-0.065 \\
(-0.300)\end{array}$ & $\begin{array}{l}0.032 \\
\quad(0.160)\end{array}$ \\
\hline Roa & $\begin{array}{r}0.159 * * * \\
(3.230)\end{array}$ & $\begin{array}{r}0.129 * * * \\
(2.760)\end{array}$ & $\begin{array}{r}0.136^{* * * *} \\
(2.780)\end{array}$ & $\begin{array}{r}0.126^{* * *} \\
(2.770)\end{array}$ & $\begin{array}{r}0.229 * * * \\
(4.870)\end{array}$ \\
\hline Lev & $\begin{array}{l}-0.004 \\
(-0.080)\end{array}$ & $\begin{array}{l}-0.034 \\
(-0.460)\end{array}$ & $\begin{array}{l}0.062 \\
(0.790)\end{array}$ & $\begin{array}{l}-0.081 \\
(-1.120)\end{array}$ & $\begin{array}{l}0.016 \\
\quad(0.230)\end{array}$ \\
\hline Growth & $\begin{array}{l}-0.006 \\
(-0.140)\end{array}$ & $\begin{array}{l}0.037 \\
\quad(0.620)\end{array}$ & $\begin{array}{l}-0.108 \\
(-0.430)\end{array}$ & $\begin{array}{l}-0.129 * \\
(-1.950)\end{array}$ & $\begin{array}{l}0.003 \\
(0.030)\end{array}$ \\
\hline Loss & $\begin{array}{l}-0.001 \\
(-0.570)\end{array}$ & $\begin{array}{r}-0.038^{* *} \\
(-2.150)\end{array}$ & $\begin{array}{l}0.002 * \\
\quad(1.860)\end{array}$ & $\begin{array}{l}0.000 \\
(-0.080)\end{array}$ & $\begin{array}{l}0.010^{* *} \\
(2.540)\end{array}$ \\
\hline Segment & $\begin{array}{l}0.012 \\
\quad(0.800)\end{array}$ & $\begin{array}{l}0.022 \\
\quad(1.500)\end{array}$ & $\begin{array}{l}0.019 \\
\quad(1.280)\end{array}$ & $\begin{array}{l}-0.007 \\
(-0.500)\end{array}$ & $\begin{array}{l}-0.024^{*} \\
(-1.780)\end{array}$ \\
\hline Opin & $\begin{array}{r}-0.391 * * * \\
(-4.990)\end{array}$ & $\begin{array}{r}-0.320 * * * \\
(-4.320)\end{array}$ & $\begin{array}{c}-0.154 * * \\
(-2.110)\end{array}$ & $\begin{array}{c}-0.169^{* *} \\
(-2.330)\end{array}$ & $\begin{array}{l}-0.119^{*} \\
(-1.920)\end{array}$ \\
\hline Big4 & $\begin{array}{r}-0.229 * * * \\
(-3.450)\end{array}$ & $\begin{array}{l}-0.289 \\
(-4.480)\end{array}$ & $\begin{array}{r}-0.262 * * * \\
(-4.360)\end{array}$ & $\begin{array}{r}-0.264 * * * \\
(-4.570)\end{array}$ & $\begin{array}{r}-0.245 * * * \\
(-4.750)\end{array}$ \\
\hline Ind & $\begin{array}{l}0.031 * \\
\quad(1.760)\end{array}$ & $\begin{array}{l}0.021 \\
\quad(1.210)\end{array}$ & $\begin{array}{l}0.029 * \\
(1.700)\end{array}$ & $\begin{array}{r}0.061 * * * \\
(3.840)\end{array}$ & $\begin{array}{c}0.032 * * \\
(2.180)\end{array}$ \\
\hline Constant & $\begin{array}{r}4.620^{* * * *} \\
(14.080)\end{array}$ & $\begin{array}{l}4.120 * * * \\
(12.770)\end{array}$ & $\begin{array}{c}4.189 * * * \\
(12.830)\end{array}$ & $\begin{array}{r}4.691 * * * \\
(15.180)\end{array}$ & $\begin{array}{r}1.832 * * * \\
(3.330)\end{array}$ \\
\hline Industry & Control & Control & Control & Control & Control \\
\hline Adj R-squared & 0.083 & 0.048 & 0.053 & 0.032 & 0.066 \\
\hline F value & $6.100 * * *$ & $3.980 * * *$ & $4.530 * * *$ & $3.290 * * *$ & $5.880 * * *$ \\
\hline
\end{tabular}

$* * * p<0.01, * * p<0.05, * p<0.1$

In order to make the research results more reliable, this paper further uses annual regression analysis to test. The results of regression analysis by year are shown in Table 6 . It can be seen in the table that the correlation between the comparability of accounting information for each year and the audit lag is basically consistent with the correlation of the entire sample, although the significance in 2016 is lower than in other years However, the sign of the coefficient is basically similar to the significance. It can be seen that the comparability of accounting information in different years is significantly positively related to the audit lag, which further confirms hypothesis $1 \mathrm{~B}$.

\subsubsection{Regression Analysis by Industry}

Table 7 Regression analysis results by industry

\begin{tabular}{lccccc}
\hline Variable & Industry1 & Industry2 & Industry3 & Industry4 & Industry5 \\
\hline \multirow{2}{*}{ Acctcompind } & $2.441^{* * *}$ & $5.788^{* * *}$ & $4.191^{* * *}$ & 0.365 & $5.868^{* * *}$ \\
& $(7.840)$ & $(5.070)$ & $(3.540)$ & $(0.340)$ & $(4.190)$ \\
Size & -0.134 & 0.162 & 0.765 & $-0.973 * *$ & 0.334 \\
& $(-1.040)$ & $(0.450)$ & $(1.520)$ & $(-2.120)$ & $(0.560)$ \\
Roa & $0.155^{* * *}$ & 0.112 & 0.070 & 0.105 & 0.096 \\
& $(5.990)$ & $(1.300)$ & $(0.700)$ & $(0.900)$ & $(0.730)$ \\
Lev & -0.004 & -0.093 & -0.136 & -0.009 & -0.249 \\
& $(-0.100)$ & $(-0.750)$ & $(-0.980)$ & $(-0.040)$ & $(-1.320)$
\end{tabular}




\begin{tabular}{lccccc} 
Growth & -0.034 & $-0.882 * * *$ & $-1.599 * *$ & $-1.417 * *$ & -0.631 \\
Loss & $(-0.940)$ & $(-2.840)$ & $(-2.420)$ & $(-2.010)$ & $(-0.740)$ \\
Segment & 0.005 & -0.001 & 0.001 & -0.001 & -0.004 \\
& $(1.860)$ & $(-0.480)$ & $(0.740)$ & $(-0.160)$ & $(-0.800)$ \\
Opin & -0.004 & 0.021 & 0.005 & -0.026 & $0.093 * * *$ \\
& $(-0.440)$ & $(0.750)$ & $(0.170)$ & $(-0.840)$ & $(2.960)$ \\
Big4 & $-0.194 * * *$ & -0.142 & -0.200 & 0.017 & -0.323 \\
& $(-4.750)$ & $(-0.970)$ & $(-1.580)$ & $(0.090)$ & $(-1.420)$ \\
Ind & $-0.274 * * *$ & $-0.239 *$ & -0.082 & $-0.171^{* *}$ & $-0.236^{* *}$ \\
& $(-7.150)$ & $(-1.680)$ & $(-0.890)$ & $(-2.240)$ & $(-2.020)$ \\
Constant & $0.035^{* * *}$ & -0.041 & $0.133 * * *$ & $0.065^{*}$ & 0.030 \\
Year & $(3.690)$ & $(-1.430)$ & $(3.970)$ & $(1.860)$ & $(0.780)$ \\
Number & $4.774 * * *$ & $4.317 * * *$ & $4.165 * * *$ & $5.198^{* * *}$ & $2.680^{* * *}$ \\
Adj R-squared & $(26.460)$ & $(7.360)$ & $(6.830)$ & $(8.380)$ & $(3.940)$ \\
Fvalue & Control & Control & Control & Control & Control \\
\hline$* * * p<0.01 * * p<0.05 * p<0.1$ & & 436 & 410 & 318
\end{tabular}

Industry 1: Wholesale and retail trade; Industry 2: Information transmission, software and information technology services; Industry 3: Electricity, heat, gas and water production and supply; Industry 4: Real estate; Industry 5: Electricity, heat, Gas and water production and supply.

There may be differences in the comparability of accounting information in different industries. Through descriptive statistics of different industries (descriptive statistics for different industries are omitted), it is found that the average value of the comparability of accounting information in the transportation, storage and postal industries is -0.0234 , standard The difference is 0.0218 , which means that the average deviation between the companies in this industry and other companies in the industry is about $2.34 \%$ of the market value, and the overall data is less scattered, and the accounting information is less comparable; The average value is -0.0097 , and the standard deviation is 0.0084 , which means that the average deviation between the companies in the education industry and other companies in their industry is about $0.97 \%$ of the market value, and the overall data is less dispersed and comparable.

Audit lags in different industries are also different. Through descriptive statistics of different industries, it is found that the average audit lag of the accommodation and catering industry is 4.323 , which is the interval between the audit report issued by the auditor and the end of the fiscal year. About 75 days; compared to other industries in agriculture, forestry, animal husbandry, and fisheries, the audit lag is generally longer, and the average audit lag is 4.789 , which represents the interval between the audit report issued by the auditor and the end of the fiscal year About 120 days or so, this is related to the characteristics of the industry, because the field audit of agriculture, forestry, animal husbandry and fishery is more difficult.

Does the comparability of accounting information in different industries affect audit lags significantly? In order to further increase the reliability of the empirical results, we re-analyzed the differences among industries by regression analysis. Due to the limitation of the number of samples in this article, the sample size of many industries after the industry is too small may affect the research results. This article selects the top five industries for the regression analysis and obtains Table 7.

It can be seen from Table 7 that the correlation of accounting information comparability to audit lag is basically consistent with the correlation of all samples. The impact of the comparability of accounting information on audit lag is mostly positive and significant. The results are not significant. This may be due to the small sample size of the real estate industry, or it may be due to the audit characteristics of the real estate industry. However, the sign of the coefficient is basically similar to the significance on the whole, which is in line with the research conclusion obtained by the full sample regression analysis.

\subsection{Robustness Analysis}

The results of the robustness test are shown in Table 8 . The empirical results show that after replacing with the variable Delayl and re-applying the multiple regression, the model results are similar to the original model regression results. The direction and significance of the coefficients of the variables have not changed for the most part. The coefficient of the annual report disclosure delay is 1.425 , and it is significant at a significant level of $1 \%$, indicating that the comparability of accounting information is positively related to the audit lag, that is, under the same other conditions, the higher the comparability of accounting information, the higher the audit The longer the report's disclosure time lags. This is basically consistent with the conclusion of 
Hypothesis $1 \mathrm{~B}$, indicating that the robustness of the model results in this paper has passed the test.

Table 8 Robustness analysis results

\begin{tabular}{|c|c|c|c|c|c|c|c|}
\hline Variable & Coefficient & $\begin{array}{c}\text { Standard } \\
\text { error }\end{array}$ & $\mathrm{T}$ value & $\mathrm{P}$ value & \multicolumn{2}{|c|}{ [ $95 \%$ confidence interval] } & $\begin{array}{c}\text { Significa } \\
\text { nce }\end{array}$ \\
\hline Acctcompind & 1.425 & 0.137 & 10.410 & 0.000 & 1.157 & 1.693 & $* * *$ \\
\hline Size & 0.013 & 0.003 & 4.000 & 0.000 & 0.006 & 0.019 & $* * *$ \\
\hline Roa & -0.218 & 0.072 & -3.040 & 0.002 & -0.359 & -0.078 & $* * *$ \\
\hline Lev & -0.048 & 0.017 & -2.850 & 0.004 & -0.080 & -0.015 & $* * *$ \\
\hline Growth & -0.014 & 0.004 & -3.320 & 0.001 & -0.023 & -0.006 & $* * *$ \\
\hline Loss & 0.019 & 0.012 & 1.590 & 0.111 & -0.004 & 0.042 & \\
\hline Segment & 0.011 & 0.003 & 3.180 & 0.001 & 0.004 & 0.017 & $* * *$ \\
\hline Opin & -0.017 & 0.016 & -1.070 & 0.283 & -0.048 & 0.014 & \\
\hline Big4 & -0.055 & 0.012 & -4.550 & 0.000 & -0.078 & -0.031 & $* * *$ \\
\hline Ind & -0.010 & 0.048 & -0.200 & 0.841 & -0.104 & 0.085 & \\
\hline Industry & & & & Control & & & \\
\hline Year & & & & Control & & & \\
\hline Constant & 4.267 & 0.068 & 62.850 & 0.000 & 4.134 & 4.400 & $* * *$ \\
\hline Adj R-squared & & 0.041 & & $\mathrm{~F}$ value & & $12.07 *$ & \\
\hline
\end{tabular}

$* * * p<0.01, * * p<0.05, * p<0.1$

\section{CONCLUSION}

In this paper, 8223 "year-company" listed company data in Shanghai and Shenzhen market from 2013 to 2017 are used as research samples to explore how the comparability of accounting information affects audit lag. It is found that under the same other conditions, the higher the comparability of accounting information, the longer the audit lag of audit report. The possible explanation is that the improvement of comparability may lead executives to adopt a more hidden way of corporate management for their own interests, that is to say, there is an increasing trend of moving opportunities from accrued earnings management to real earnings management. First of all, the management wants to take real earnings management to achieve the profit objectives and expectations, because the company's operating conditions are closely related to the incentives of the management, and achieving the profit objectives can bring economic benefits to the management. The existence of this kind of management incentive will make the management carry out real earnings management more frequently, so as to achieve the profit goal and obtain the bonus or subsidy linked to the company's performance. The second motivation is to influence the accounting information transmitted to the market. The company hopes to whitewash its statements through real earnings management and "improve" the company's financial situation, thus sending a positive signal to the market that the company has investment value and attracts investors. The last is that the company hopes to influence the relevant interest groups through real earnings management, such as avoiding the supervision of government departments, avoiding the legal settlement and reducing the risk of being audited. Real earnings management is not easy to be found by auditors as accrual earnings management is, without violating accounting standards. Therefore, the company reduces the accrual earnings management and uses the real earnings management instead. However, it also increases the risk and complexity of the audit, making the audit more difficult, which will lead the auditors to invest more energy and spend more time to reduce the audit risk. The disclosure date of audit report will be delayed, that is, the audit delay will be extended.

\section{REFERENCES}

[1] $\mathrm{Gu}$ Ye."Research review and future outlook on comparability of accounting information" , Journal of decision and information, School of economics and management, Peking University. "Decision Forum Academic Seminar on innovation of enterprise management mode". Journal of decision and information, School of Economics and management, Peking University: Editorial Department of science and technology and enterprise, 2017:2.

[2] Liu Yanghui. "Signed CPA\&apos;s industry expertise and comparability of accounting information ",Financial theory and practice, 2018,39 (03): 98-104.

[3] Franco G D, Kothari S P, Verdi R S. "The Benefits of Financial Statement Comparability[J]. Journal of Accounting Research”,2011,49(4):895-931.

[4] Xue Yuhua, Zhang Pengcheng. "Research on the influencing factors of accounting information comparability -- Empirical Evidence from Listed Companies ”,Friends of accounting, 2015 (22): 17-21.

[5] Kim S,Kraft P, Ryan S G. "Financial statement comparability and credit risk", Social Science Electronic Publishing,2013,18(3):783-823.

[6] Cheng Meng, Liu Ruizhi. "Research on the influence of accounting information comparability on audit quality -Based on the empirical evidence of A-share listed companies in China", Accounting communication, 2016 (24): 34-36.

[7] Chen Yue, Jiang Xuanyu "Can comparability of accounting information reduce audit fees? -- Based on the dual analysis of information environment and agency issues ", Audit research, 2017 (02): 89-97.

[8] Sun Lixia. "Does the improvement of comparability of accounting information reduce the audit cost?"Chinese certified public accountant, 2016 (04): 64-68.

[9] Yan Min, Qu Chenchen. "The impact of accounting information comparability on earnings management",Friends of accounting, 2017 (21): 75-81.

[10] Shi Jun. "Accrued earnings management, real earnings management and audit report delay ", Shandong University 
[28] Li Yingmei, Chu Youwei, Yang Zhonghai. "Research on the influencing factors of audit delay in annual report: from the perspective of internal control quality grouping", Chinese certified public accountant, 2015 (6): 50-56. of Finance and economics, 2015.

[11] Lan Hao. "Empirical research on real earnings management, accounting restatement and audit report delay ",Shandong University, 2015.

[12] Xie Shengwen, Deng Ziqi, Wang Qing. "Comparability of accounting information and audit decision of Certified Public Accountants -- Empirical Evidence from China\&apos;s securities market",Audit and economic research, 2017,32 (05): 10-19.

[13] Chen Xiangyu, Xiao Hong, Wan Peng. "Comparability of accounting information, information environment and accuracy of performance forecast ",Financial forum, 2015 (10): 58-66.

[14] Liu Yali, Shi Lei, Zhao Yang. "Audit delay, disclosure delay and information delay: analysis of influencing factors and differences",China management informatization, 2011,14 (1): 24-30.

[15] Gong Q , Li O Z, Lin Y, et al. "On the Benefits of Audit Market Consolidation: Evidence from Merged Audit Firms", Social Science Electronic Publishing, 2015-08-01.

[16] Habib A, Bhuiyan M B U. "Audit firm industry specialization and the audit report lag", Journal of International Accounting Auditing \& Taxation, 2011, 20(1):32-44.

[17] Chen Gaocai. "Does the characteristics of accounting firm affect the time lag of audit report",Financial and economic review, 2012 (01): 91-96.

[18] Chan K H, Luo V W, Mo P L L. "Determinants and implications of long audit reporting lags: evidence from China", Accounting \& Business Research, 2016, 46(2):1-22.

[19] Yang mingzeng, Shi Jun, Zhang Jiacong. "Research on audit mode, customer business risk and time lag effect of audit report -- Based on the empirical evidence of Shanghai and Shenzhen stock markets from 2003 to 2011", Economic and management review, 2014,30 (06): 54-62.

[20] Zhang Huijun. "Research on the factors influencing the time lag of audit report of Listed Companies", Financial supervision, 2017 (20): 91-96.

[21] Joseph H,Zhang. "Accounting Comparability, Audit Effort,and Audit Outcomes "Contemporary Accounting Research,2017,35(1):245-276.

[22] Yuan Zhenchao, Wei Xiaoquan. "Comparability of accounting information, auditor industry expertise and audit delay ",Accounting and economic research, 2018,32 (01): 72-88.

[23] Zang A Y. "Evidence on the Trade-Off between Real Activities Manipulation and Accrual-Based Earnings Management",Accounting Review,2012,87(2):675-703.

[24] Xu Chaoyang, Liu Ruizhi. "How to improve the comparable performance of accounting information to inhibit earnings management? ", Accounting research, 2014 (07): $50-57+97$

[25] Xing Liquan, Wang Weicheng, Chen Hanwen. "Product market competition, competitive position and earnings management", Journal of Nanjing University of audit, 2016 (3): $30-43$.

[26] Ahrum Choi,Byungcherl Charlie Sohn,Desmond Yuen. Do auditors care about real earnings management in their audit fee decisions?, Asia-Pacific Journal of Accounting \& Economics,2018,25(1-2).

[27] Wang chunfei, Lu Zhengfei, Wu Lina. "Unified audit of enterprise groups and cost of equity capital", Accounting research, 2013 (6): 75-82. 